\title{
ALUMNI ASSESSMENT ON THE QUALITY OF SERVICES AND CURRICULUM RELEVANCE OF PROGRAM STUDY SPORTS SCIENCE FIK UNY
}

\author{
Sigit Nugroho ${ }^{1 *}$, Ahmad Nasrulloh ${ }^{1}$, Sumaryanto ${ }^{1}$, Sumarjo $^{1}$, Duwi Kurnianto ${ }^{1}$. \\ ${ }^{1}$ Ilmu Keolahragaan, Fakultas Ilmu Keolahragaan, Universitas Negeri Yogyakarta, Jl. Colombo No. 1, \\ Karangmalang, Depok, Sleman, Daerah Istimewa Yogyakarta, Indonesia. \\ *sigit.nugroho@uny.ac.id,ahmadnasrulloh@uny.ac.id, sumaryanto@uny.ac.id,duwi.kp@uny.ac.id.
}

\begin{abstract}
This research is a quantitative descriptive study which aims to obtain an overview of alumni assessments in providing service quality and the relevance of the curriculum of the Sport Science Study Program, Faculty of Sport Sciences, Yogyakarta State University. The data collection method used a questionnaire with variables consisting of 1) the quality of financing services and academic activities 2) the waiting period of work, 3) the competence of graduates, and 4) the relevance of the curriculum. The population of this study were all graduates of the Ikor Study Program. Sampling with snowball sampling technique with a total of 113 samples. The research instrument used a questionnaire while for data collection techniques using google form. Data analysis was carried out by means of quantitative descriptive analysis. The results of the study show that the service quality of the Ikor study program in financing is very good, it is known that the tuition fees are $26.55 \%$ with scholarships and $73.45 \%$ at their own expense. Meanwhile, the quality of service in academic activities was good at $79.27 \%$. Ikor Study Program graduates in obtaining employment amounted to $65.49 \%$ after graduating with an average of 3.47 months and before graduating $34.51 \%$ with an average of 5.23 months. The overall competence of graduates was very good, namely $85.3 \%$, the most prominent being competence in working with teams or with other people, namely $88.5 \%$. The results of the relevance of the curriculum are included in the very good category, namely $85.93 \%$, in the relevance of the curriculum from the alumni assessment, the highest percentage of $90.97 \%$ was found in practice subjects that were delivered during lectures very well according to work needs. So as a whole it can be concluded that most of the alumni assessments in providing service quality and curriculum relevance are very good.
\end{abstract}

Keywords: alumni, service quality, curriculum

\section{PENILAIAN ALUMNI TERHADAP MUTU LAYANAN DAN RELEVANSI KURIKULUM PROGRAM STUDI ILMU KEOLAHRAGAAN FIK UNY}

\begin{abstract}
Abstrak
Penelitian ini merupakan penelitian deskriptif kuantitatif yang bertujuan untuk memperoleh gambaran tentang penilaian alumni dalam menyelenggarakan mutu layanan dan relevansi kurikulum Program Studi Ilmu Keolahragaan Fakultas Ilmu Keolahragaan Universitas Negeri Yogyakarta. Metode pengumpulan data menggunakan kuisioner dengan variabel yang terdiri dari 1) mutu layanan pembiayaan dan kegiatan akademik 2) masa tunggu pekerjaan, 3) kompetensi lulusan, dan 4) relevansi kurikulum. Populasi penelitian ini adalah seluruh lulusan Prodi Ikor. Pengambilan sampel dengan teknik snowball sampling dengan jumlah 113 sampel. Instrumen penelitian menggunakan kuisioner sedangkan untuk teknik pengumpulan data dengan google form. Analisis data dilakukan dengan jalan analisis deskriptif kuantitatif. Hasil penilitian menunjukan bahwa mutu layanan prodi Ikor dalam pembiayaan sangat baik, diketahui bahwa pembiayan kuliahnya sebesar 26,55 \% dengan beasiswa dan sebesar 73,45 $\%$ dengan biaya sendiri. Sedangkan mutu layanan pada kegiatan akademik hasilnya baik yaitu sebesar $79,27 \%$. Lulusan Prodi Ikor dalam memperoleh pekerjaan sebesar 65,49\% sesudah lulus dengan rata-
\end{abstract}


rata sebesar 3,47 bulan dan sebelum lulus sebesar 34,51\% dengan rata-rata sebesar 5,23 bulan. Kompetensi lulusan secara keseluruhan sangat baik yaitu 85,3\% yang paling menonjol kompetensi dalam bekerjasama dengan tim atau dengan orang lain yaitu sebesar 88,5\%. Hasil relevansi kurikulum masuk dalam kategori sangat baik yaitu sebesar 85,93 \%, dalam relevansi kurikulum dari penilaian alumni persenstase yang paling tinggi yaitu sebesar 90,97\% terdapat pada matakuliah praktik yang disampaikan saat kuliah sangat sesuai dengan kebutuhan kerja. Sehingga secara keseluruhan dapat disimpulkan bahwa penilaian alumni dalam penyelenggaraan mutu layanan dan relevansi kurikulum sebagian besar menyatakan sangat baik.

Kata kunci: alumni, mutu layanan, kurikulum

\section{PENDAHULUAN}

Pendidikan dalam Undang-Undang No 12 tahun 2012 merupakan suatu usaha yag secara sadar dan terencana dalam mewujudkan suasana belajar dan proses pembelajaran pada peserta didik secara aktif dalam mengembangkan potensi diri sehingga memiliki kekuatan spiritual, pengendalian, kepribadian, kecerdasan, akhlak mulia, dan keterampilan yang diperlukan dalam bermasyarakat, berbangsa, dan bernegara. Jenjang Pendidikan di Indonesia dikenal dari tingkat dasar, Tingkat Menengah, Sekolah Menengah, Sekolah Menengah Kejuruan dan Sekolah Tinggi yang berkelanjutan sesuai dengan tingkatan yang ditempuh dan dilalui oleh siswa Indonesia yang memiliki tujuan salah satunya sesuai dengan amanat pembukaan Undang Undang Dasar 1945 "memajukan kesejahteraan umum, mencerdaskan kehidupan bangsa" yang salah satu caranya adalah mengisi pembangunan Negara Indonesia dengan menempuh pendidikan setinggi dan sebaik mungkin sehingga pada saatnya nanti generasi muda calon pemimpin bangsa siap untuk memajukan negara dan bangsa Indonesia melalui kemampuan dan bekal yang dimiliki melalui pendidikan.

Perguruan tinggi atau lembaga pendidikan tinggi di Indonesia memiliki tanggungjawab sebagai penyelenggara, penyedia dan pendidik bagi generasi muda calon-calon pemimpin, pengisi dimasa yang akan datang. Maju atau tidaknya suatu negara salah satunya adalah faktor Sumber Daya Manusia (SDM) yang memiliki kompetensi, dan kualifikasi sehingga siap dalam mengarungi dunia baik dalam dunia kerja, rasa bela negara, maupun dunia sosial kemasyarakatan. Kesadaraan akan tingkat pendidikan lanjut di Indonesia sangat didukung sepenuhnya oleh pemerintah. Bantuan-bantuan beasiswa dengan berbagai macam skim yang memiliki tujuan agar pendidikan tinggi dapat dinikmati oleh seluruh warga negara Indonesia tanpa terkecuali. Setiap tahun Perguruan Tinggi membuka seleksi masuk untuk diterima menjadi mahasiswa pada salah satu program studi dari Perguruan Tinggi yang sudah dipilih dengan bersaing satu dengan lainnya untuk bisa diterima menjadi mahasiswa. Sejalan dengan Penerimaan Mahasiswa Baru yang jumlahnya besar, tentunya Perguruan Tinggi juga harus melakukan wisuda mahasiswa yang sudah dinyatakan lulus dan berhak menyantumkan gelar Sarjana juga disetiap tahunnya, Universitas Negeri Yogyakarta dalam 1 tahun kalender akademik melakukan 4 kali wisuda dengan rata-rata 500-1000an wisudawan disetiap wisudanya.

Program Studi adalah kesatuan kegiatan Pendidikan dan pembelajaran yang memiliki kurikulum dan metode pembelajaran tertentu dalam satu jenis pendidikan akademik, pendidikan profesi, dan/atau pendidikan vokasi. (Pasal 1 ayat 17 UU No 12 th 2012). Program sarjana merupakan pendidikan akademik yang diperuntukkan bagi lulusan pendidikan menengah atau sederajat sehingga mampu mengamalkan Ilmu Pengetahuan dan Teknologi melalui penalaran ilmiah. Program sarjana sebagaimana dimaksud pada ayat (1) menyiapkan Mahasiswa menjadi intelektual dan/atau ilmuwan yang berbudaya, mampu memasuki dan/atau menciptakan lapangan kerja, serta mampu mengembangkan diri menjadi profesional. (UU No 12 Tahun 2012 Pasal 18 ayat 1,2) 
Program Studi Ilmu Keolahragaan (Prodi Ikor) Fakultas Ilmu Keolahragaan Universitas Negeri Yogyakarta didirikan pada tahun 1999 berdasarkan SK direktur Jendral Pendidikan Tinggi No. 2951/D/T/2003. Sedangkan perpanjangan ijin operasional prodi diberikan oleh Rektor UNY melalui SK Rektor No. 8291/D/T/KN/2001. Prodi Ikor telah mendapatkan tiga kali Akreditasi A dari Badan Akreditasi Nasional Perguruan Tinggi (BAN-PT) sejak tahun 2006. Saat ini Akreditasi A pada Prodi IKOR diberikan oleh Kementrian Riset dan Teknologi Dikti berdasarkan Keputusan BAN-PT No. 1183/SK/BAN-PT/Akred/S/VII/2016, yang berlaku sejak tahun 2016 sampai dengan 2021.

Prodi Ikor UNY juga menjadi anggota sekaligus pengurus Organisasi Profesi prodi IKOR se-Indonesia yang sudah berbadan hukum dalam bentuk Perkumpulan Program Studi Ilmu Keolahragaan Indonesia (P2SIKI), dengan SK Menteri Hukum dan hak Asasi manusia Repinlik Indonesia Nomor AHU-0017068.AH.01.07.Tahun 2007. Pengembangan kurikulum prodi Ikor memperhatikan beberapa hal, yaitu (1) Perubahan visi misi UNY, (2) Era revolusi Industri 4.0, (3) Pendidikan abad 21, (4) KKNI, (5) Technologycal and Pedagogical Content Knowledge (TPACK), (6) World Class Univesity (WCU) dan (7) Standar Kurikulum Nasional Program S1 Ikor dari P2SIKI. Prodi Ikor menyelenggarakan pendidikan akademik dengan tujuan menghasilkan lulusan dalam bidang keolahragaan dengan kualifikasi sarjana S1 non kependidikan dengan gelar Sarjana Olahraga (S.Or) yang nasionalis, tangguh, jujur, bertanggungjawab dan tanggap terhadap tuntutan perkembangan keolahragaan. Nama Prodi Ikor dan gelar lulusan (S.Or) telah sesuai dengan nomenklatur Kemenristek Dikti RI Nomor 257/M/KPT/2017 dan SK Dirjen Belmawa Nomor 46/B/HK/2019. Lulusan Prodi Ikor memiliki kompetensi sebagai tenaga terampil dalam konsentrasi Kebugaran Jasmani, Terapi dan Rehabilitasi Fisik, Aktivitas Fisik Adaptif dan Manajemen Olahraga.

Perguruan Tinggi di Indonesia sebagai salah satu wadah/ tempat mendidik dan mempersiapkan diri bagi generasi muda calon-calon pemimpin, pengisi negara Indonesia dimasa yang akan datang. Maju atau tidaknya suatu negara salah satunya adalah faktor Sumber Daya Manusia (SDM) yang memiliki kompetensi, dan kualifikasi sehingga siap dalam mengarungi dunia baik dalam dunia kerja, rasa bela negara, maupun dunia sosial kemasyarakatan. Perubahan merupakan hal yang niscaya dalam kehidupan manusia. Demikian pula orientasi pendidikan yang semula bertumpu pada asumsi ilmu untuk ilmu mengalami perubahan menjadi ilmu untuk kemanfaatan hajat hidup orang banyak. Pertanyaan yang sering muncul setelah seseorang menyelesaikan jenjang pendidikan tinggi ialah akan kerja apa, di mana, dan untuk siapa. Pertanyaan tersebut mengindikasikan perubahan kesadaran sekaligus harapan bahwa pengetahuan dan keterampilan yang diperoleh di bangku kuliah dapat bermanfaat bagi orang lain melalui karya nyata sang sarjana.

Banyaknya jumlah Alumni disetiap tahun yang diluluskan, maka perlu adanya sebuah penelusuran atau tracer study untuk mengetahui akan serapan tentang pekerjaan dan sebagai evaluasi untuk program studi. Manfaat tracer study tidaklah terbatas pada perguruan tinggi saja, tetapi lebih jauh lagi dapat memberikan informasi penting mengenai hubungan (link) antara dunia pendidikan tinggi dengan dunia kerja. Tracer study dapat menyajikan informasi mendalam dan rinci mengenai kecocokan/match kerja baik horisontal (antar berbagai bidang ilmu) maupun vertikal (antar berbagai level/strata pendidikan). Tracer study dapat membantu mengatasi permasalahan kesenjangan kesempatan kerja dan upaya perbaikannya. Bagi universitas, informasi mengenai kompetensi yang relevan bagi dunia kerja dapat membantu upaya perbaikan mutu kurikulum dan sistem pembelajaran. Mutu adalah apa yang diharapkan atau ditentukan oleh konsumen (Muninjaya, 2011). Suryatama (2014) mendefinisikan bahwa mutu adalah gambaran karakteristik langsung dari suatu produk. Kualitas bisa diketahui dari segi bentuk, penampilan, performa suatu produk, dan juga bisa dilihat dari segi fungsinya serta segi estetisnya. Mubarak dan Chayatin (2009) mendefinisikan mutu atau kualitas adalah kesesuaian dengan kebutuhan pasar atau konsumen. Dari beberapa definisi tersebut, maka 
dapat diketahui bahwa mutu adalah ukuran yang dibuat oleh konsumen terhadap produk atau jasa yang dilihat dari segala dimensi atau karakteristik untuk memenuhi tuntutan kebutuhan, keamanan, dan kenyamanan konsumen.

Keberhasilan lulusan Perguruan Tinggi dalam memasuki dunia kerja merupakan salah satu indikator outcome pembelajaran dan relevansi PT bagi masyarakat. Perguruan Tinggi bertanggung jawab tidak hanya untuk melengkapi lulusan dengan kompetensi tertentu (output pembelajaran) tetapi juga wajib memfasilitasi dan menjembatani lulusan memasuki dunia kerja. Keberadaan Pusat Karir di Perguruan Tinggi mencerminkan tanggung jawab dan layanan Perguruan Tinggi bagi lulusan baru pada khususnya, dan mahasiswa pada umumnya sebagai calon lulusan (Kemenristekdikti, 2016: 4). Sehubungan dengan proses pemberian pelayanan, maka terdapat beberapa dimensi atau ukuran yang dapat dilihat melalui kacamata mutu. Karakteristik dari mutu pelayanan terdiri dari sepuluh dimensi pokok diantaranya meliputi daya tanggap, kehandalan, kompetensi, kesopanan, akses, komunikasi, kredibilitas, kemampuan memahami pelanggan, keamanan dan bukti fisik (Mukti, 2007). Sedangkan mutu pelayanan sesuai pendapanya Fitzsimmons dan Fitzsimmons (2011) terdiri dari lima aspek yang mempengaruhi, yaitu: Realibility, Tangibles, Responsiveness, Assurance, dan Empaty.

Tracer study berperan penting, sebagai tahap awal pengembangan kurikulum pendidikan tinggi yang baru, misalnya. Tracer study pun menjadi salah satu syarat kelengkapan akreditasi oleh Badan Akreditasi Nasional Perguruan Tinggi (BAN-PT) dan juga kelengkapan dokumen evaluasi diri yang diperlukan dalam pengajuan proposal Akredikasi/Reakreditasi Prodi. Demikian pula secara kelembagaan, lembaga pendidikan ditagih oleh stakeholders tentang kiprah nyata mencerdaskan generasi bangsa dalam wujud melahirkan lulusan yang berkualitas secara akademis maupun yang anggun kepribadiannya. Untuk melaksanakan cita-cita mulia tersebut, lembaga pendidikan dituntut untuk terus mereorganisasi dirinya dan meningkatkan kualitas layanan pendidikan kepada public. Salah satunya melalui penilaian kinerja program studi oleh Badan Akreditasi Nasional Perguruan Tinggi (BAN PT) dan penyusunan laporan Evaluasi Diri sebagai dasar pijakan konsolidasi organisasi dan pengembangan program kegiatan akademik. Salah satu butir evaluasi diri dan isian borang akreditasi ialah mengenai keberadaan lulusan setelah meninggalkan bangku kuliah.

Kementerian Riset dan Pendidikan Tinggi pada tahun 2017 telah mengeluarkan Surat Edaran No. 471/B/SE/VII/2017 Tentang Pelaksanaan Tracer Study di Perguruan Tinggi yang di dalamnya mengatur tentang populasi, kuisioner dan pelaporan tentang hasil Tracer Study (Kemenristekdikti, 2017). Merujuk pada edaran tersebut pada penelitian ini menggunakan Kuisioner dari Kemenristekdikti dengan melakukan penyesuaian sesuai dengan yang dibutuhkan oleh program studi Ilmu Keolahragaan FIK UNY.

\section{METODE}

Penelitian ini merupakan penelitian deskriptif kuantitatif. Metode yang digunakan dalam penelitian ini adalah metode survei. Teknik pengumpulan data yang digunakan dalam penelitian ini menggunakan alat yang berupa angket. Penelitian ini bertujuan untuk mengetahui keadaan suatu objek yaitu Profil Alumni Prodi Ilmu Keolahragaan FIK UNY. Penelitian ini berfokus kepada Alumni Program Studi Ilmu Keolahragaan Fakultas Ilmu Keolahragaan yang telah menyelesaikan dan lulus Program Sarjana (S-1) Ilmu Keolahragaan di Program Studi Ilmu Keolahragaan FIK UNY. Pengambilan sampel dengan teknik snowball sampling dengan jumlah 113 sampel.

Instrumen dalam penelitian ini menggunakan angket atau kuesioner. Teknik pengumpulan data dengan memberikan angket kepada Alumni, baik melalui media angket cetak ataupun dengan membuatkan formulir angket melalui Google Form. Sugiyono (2012 : 142) kuesioner merupakan teknik pengumpulan data yang dilakukan dengan cara memberi seperangkat pertanyaan atau pernyataan tertulis kepada responden untuk dijawabnya. Dalam 
penelitian ini angket yang digunakan oleh peneliti adalah angket tertutup, karena responden tinggal memilih salah satu jawaban yang sudah disediakan pada lembar jawaban.

Teknik analisis data yang digunakan dalam penelitian ini adalah analisis deskriptif kuantitatif dengan persentase. Frekuensi relatif atau tabel persentase dikatakan "frekuensi relatif" sebab frekuensi yang disajikan di sini bukanlah frekuensi yang sebenarnya, melainkan frekuensi yang dituangkan dalam bentuk angka, sehingga untuk menghitung persentase responden digunakan rumus sebagai berikut:

$$
\mathrm{P}=\frac{F}{N} \times 100 \%
$$

Keterangan:

$\mathrm{P}:$ Angka persentase

F : Frekuensi

$\mathrm{N}$ : Jumlah subjek atau responden

Hasil perhitungan data selanjutnya dalam bentuk persentase dengan dikalikan $100 \%$. Setelah diperoleh persentase dengan rumus tersebut, selanjutnya dimasukan dalam kategori penilaian. Sesuai pendapatnya Arikunto (2013: 44) ada 5 dalam pembagaian kategori. Nilai maksimal yang diharapkan adalah $100 \%$ dan minimal $0 \%$. Pembagian rentang kategori menggunakan skala sebagai berikut:

Tabel 1. Kategori penilaian

\begin{tabular}{lcl}
\hline No & Skor dalam persentase & Kategori penilaian \\
\hline 1 & $<21 \%$ & Sangat tidak baik \\
2 & $21-40 \%$ & Tidak baik \\
3 & $41-60 \%$ & Cukup baik \\
4 & $61-80 \%$ & Baik \\
5 & $81-100 \%$ & Sangat Baik \\
\hline
\end{tabular}

\section{HASIL DAN PEMBAHASAN}

Hasil penelitian diperoleh data yang relevan dengan angket tracer study alumni prodi Ikor FIK UNY. Penyajian data hasil penelitian dapat berupa tabel, grafik, gambar atau bagan yang disusun sesuai tahapan pelaksanaan penelitian. Data penelitian ini didapat dari lulusan Prodi IKORA FIK UNY. Data yang terkumpul sebanyak 113 responden yang diberikan angket sesuai dengan variabel penelitian. Deskripsi hasil penelitian yang dilakukan dapat dilihat seperti di bawah ini:

1. Mutu Layanan

Data yang berkaitan dengan mutu layanan diperoleh dari penilaian alumni yang terdiri dari pembiayaan dan kegiatan akademik. Hasil data yang berkaitan dengan pembiayaan dan kegiatan akademik dapat dijabarkan sebagai berikut:

a. Pembiayaan

Dalam data pembiayaan diindentifikasi dari biaya yang berkaitan dengan beasiswa dan pembiayaan secara mandiri. Pembiayaan beasiswa terdiri dari beasiswa bidikmisi, PPA, perusahaan swasta dan beasiswa dari BANK. Hasil data pembiayaan dapat dilihat pada tabel 2 berikut:

Tabel 2. Data hasil pembiayaan

\begin{tabular}{llcc}
\hline No & Pembiayaan & Jumlah & Persentase \\
\hline 1 & Beasiswa & 30 & $26,55 \%$ \\
2 & Biaya sendiri & 83 & $73,45 \%$ \\
\hline & Total & 113 & $100 \%$ \\
\hline
\end{tabular}


b. Kegiatan Akademik

Dalam data akademik ditekankan pada metode pembelajaran yang meliputi perkuliahan, demonstrasi, partisipasi dalam proyek riset, magang, praktikum, kerja lapangan dan diskusi. Hasil data kegiatan akademik dapat dilihat pada tabel 3 berikut:

Tabel 3. Data hasil kegiatan akademik

\begin{tabular}{lccc}
\hline No & $\begin{array}{c}\text { Skor } \\
\text { Persentase }\end{array}$ & Jumlah & Kategori \\
\hline 1 & $<21 \%$ & 0 & Sangat tidak baik \\
2 & $21-40 \%$ & 1 & Tidak baik \\
3 & $41-60 \%$ & 11 & Cukup baik \\
4 & $61-80 \%$ & 52 & Baik \\
5 & $81-100 \%$ & 49 & Sangat Baik \\
\hline & Total & 113 & \\
\hline
\end{tabular}

Secara keseluruhan dari mutu layanan dalam kegiatan akademik dapat diperoleh hasil seperti pada tabel 4 sebagai berikut:

Tabel 4. Data hasil secara keseluruhan dalam kegiatan akademik

\begin{tabular}{ccccc}
\hline Sampel & $\begin{array}{l}\text { Hasil diperoleh } \\
\text { kegiatan akademik }\end{array}$ & $\begin{array}{l}\text { Hasil Harapan } \\
\text { kegiatan akademik }\end{array}$ & $\begin{array}{l}\text { Persentase } \\
\text { keseluruhan }\end{array}$ & Kategori \\
\hline 113 & 3131 & 3955 & 79,27 & Baik \\
\hline
\end{tabular}

2. Masa Tunggu Pekerjaan

Data dalam masa tunggu pekerjaan dibagi menjadi dua kategori yaitu memperoleh pekerjaan sesudah lulus dan memperoleh pekerjaan sebelum lulus. Hasil data masa tunggu pekerjaan dapat dilihat pada tabel 5 berikut:

Tabel 5. Data hasil masa tunggu pekerjaan

\begin{tabular}{cccccc}
\hline No & Keterangan lulus & Sampel & Persentase & Waktu Tunggu (bulan) & Mean \\
\hline 1 & Sesudah Lulus & 74 & 65,49 & 257 & 3,47 \\
2 & Sebelum Lulus & 39 & 34,51 & 204 & 5,23 \\
\hline & Jumlah & 113 & 100 & & \\
\hline
\end{tabular}

3. Kompetensi Lulusan

Data kompetensi lulusan diketahui dari beberapa kompetensi yang dibagai menjadi tiga indikator diantaranya yaitu: pengetahuan, sikap dan Keterampilan. Hasil data kompetensi lulusan secara keseluruhan dapat dilihat pada tabel 6 berikut:

Tabel 6. Data Kompetensi Lulusan

\begin{tabular}{ccccccc}
\hline No & Keterangan & Sampel & $\begin{array}{c}\text { Hasil } \\
\text { diperoleh }\end{array}$ & $\begin{array}{c}\text { Hasil } \\
\text { Harapan }\end{array}$ & Persentase & Kategori \\
\hline 1 & $\begin{array}{c}\text { Kompetensi } \\
\text { Lulusan }\end{array}$ & 113 & 13976 & 16385 & $85,30 \%$ & Sangat Baik \\
\hline
\end{tabular}

Apabila ditinjau dari indikator kompetensi lulusan yang terdiri dari pengetahuan, sikap dan keterampilan hasilnya dapat dilihat pada tabel 7 berikut:

Tabel 7. Jenis Kompetensi Lulusan

\begin{tabular}{clc}
\hline No & Kompetensi Lulusan & Persentase \\
\hline 1 & Pengetahuan & 13,20 \\
2 & Sikap & 17,66 \\
3 & Keterampilan & 69,14 \\
\hline & Jumlah & $100 \%$ \\
\hline
\end{tabular}


4. Relevansi Kurikulum

Data relevansi kurikulum dengan perkembangan ilmu pengetahuan dan teknologi dengan kebutuhan kerja diketahui dari beberapa hal diantaranya perkuliahan teori, praktik, materi, pengalaman PKL, kurikulum, dosen, iklim perkuliahan, dan kegiatan mahasiswa. Hasil data relevansi secara keseluruhan dapat dilihat pada tabel 8 berikut:

Tabel 8. Data Relevansi Kurikulum

\begin{tabular}{lccc}
\hline No & Skor Persentase & Jumlah & Kategori \\
\hline 1 & $<21 \%$ & 0 & Sangat tidak baik \\
2 & $21-40 \%$ & 0 & Tidak baik \\
3 & $41-60 \%$ & 3 & Cukup baik \\
4 & $61-80 \%$ & 45 & Baik \\
5 & $81-100 \%$ & 65 & Sangat Baik \\
\hline & Total & 113 & \\
\hline
\end{tabular}

Secara keseluruhan relevansi kurikulum dapat diperoleh hasil seperti pada tabel 9 sebagai berikut:

Tabel 9. Data hasil secara keseluruhan Relevansi Kurikulum

\begin{tabular}{ccccc}
\hline Sampel & $\begin{array}{l}\text { Hasil diperoleh } \\
\text { kegiatan akademik }\end{array}$ & $\begin{array}{l}\text { Hasil Harapan } \\
\text { kegiatan akademik }\end{array}$ & $\begin{array}{l}\text { Persentase } \\
\text { keseluruhan }\end{array}$ & Kategori \\
\hline 113 & 4370 & 5085 & 85,93 & Sangat Baik \\
\hline
\end{tabular}

\section{PEMBAHASAN}

Berdasarkan dari hasil penelitian dan disajikan dalam deskripsi hasil penelitian. Data penelitian ini didapat dari lulusan Prodi IKOR FIK UNY. Penelitian ini berfokus kepada Mutu Layanan, Masa Tunggu Pekerjaan, Kompetensi Lulusan dan relevansi Kurikulum dengan menggunakan data yang terkumpul sebanyak 113 responden. Tujuan Penelitian tracer study berdasarkan Fajaryati et all (2015: 44) untuk memperoleh gambaran lama masa tunggu alumni sampai mendapatkan pekerjaan, mendeskripsikan penilaian alumni mengenai penyelenggaraan dan mutu layanan program yang ada di Program Studi dan mendeskripsikan penilaian pengguna alumni terhadap kompetensi lulusan.

Data Mutu Layanan yang berkaitan dengan mutu layanan diperoleh dari penilaian alumni yang terdiri dari pembiayaan dan kegiatan akademik. Mutu sesuai pendapatnya Bustami (2011) merupakan perpaduan sifat-sifat dan karakteristik produk atau jasa yang dapat memenuhi kebutuhan pemakai atau pelanggan. Model ServQual salah satu model yang banyak dipakai untuk mengukur kepuasan pelanggan dengan cara membuat penilaian kepuasan pelanggan secara komprehensif bagi pelayanan di bidang barang dan jasa yang mengutamakan aspek pelayanan (Mas'ud, 2009). Hasil data yang berkaitan dengan mutu pembiayaan diindentifikasi dari biaya yang berkaitan dengan beasiswa dan pembiayaan secara mandiri. Pembiayaan beasiswa terdiri dari beasiswa bidikmisi, Peningkatan Prestasi Akademik (PPA), perusahaan swasta dan beasiswa dari perbankan. Dari 113 orang 83 orang $(73,45 \%)$ dengan biaya sendiri, sedangkan 20 orang $(26,55 \%)$ mendapatkan beasiswa.

Tracer study dapat menyediakan informasi untuk kepentingan evaluasi hasil pendidikan tinggi dan selanjutnya dapat digunakan untuk penyempurnaan dan penjaminan kualitas lembaga pendidikan tinggi bersangkutan. tracer study berperan penting, sebagai tahap awal pengembangan kurikulum pendidikan tinggi yang baru (Kemenristekdikti, 2016: 4-5). Kegiatan Akademik adalah metode pembelajaran yang meliputi perkuliahan, demonstrasi, partisipasi dalam proyek riset, magang, praktikum, kerja lapangan dan diskusi. Hasil data kegiatan akademik dari 113 responden 1 orang memberikan nilai Tidak Baik (21\%-40\%), 11 orang memberikan nilai Cukup Baik (41\%-60\%), 52 orang memberikan nilai Baik (61\%$80 \%), 49$ orang memberikan nilai Sangat Baik (81\%-100\%). Secara keseluruhan dari mutu 
layanan dalam kegiatan akademik memperoleh hasil 3131 poin dari 3955 poin nilai maksimal, sehingga masuk dalam kategori Baik $(79,27 \%)$.

Keberhasilan lulusan Perguruan Tinggi (PT) dalam memasuki dunia kerja merupakan salah satu indikator outcome pembelajaran dan relevansi PT bagi masyarakat (Kemenristekdikti, 2016: 4). Tracer Study berupaya untuk meninjau situasi kerja khususnya di masa-masa awal ketika seorang lulusan memasuki dunia kerja. Salah satu aspek yang dinilai adalah masa Tunggu Pekerjaan, masa tunggu pekerjaan dibagi menjadi dua kategori yaitu memperoleh pekerjaan sesudah lulus dan memperoleh pekerjaan sebelum lulus. Hasil data lulusan yang bekerja sesudah lulus berjumlah 74 orang $(65,49 \%)$ Hasil data lulusan yang bekerja sebelum lulus berjumlah 39 orang $(34,51 \%)$.

Data kompetensi lulusan diketahui dari beberapa kompetensi yang dibagai menjadi tiga indikator diantaranya yaitu: pengetahuan, sikap dan keterampilan. Hasil data kompetensi lulusan secara keseluruhan memperoleh nilai 13976 poin dari 16385 poin maksimal, sehingga mendapatkan kategori Sangat Baik (85,30\%). Kompetensi lulusan berdasarkan aspek Pengetahuan mendapatkan presentase 13,20 \%, aspek Sikap 17,66\%, Aspek ketrampilan $69,14 \%$ dengan total $100 \%$.

Tracer study juga dapat memberikan informasi mengenai output pendidikan yaitu penilaian diri terhadap penguasaan dan pemerolehan kompetensi, proses pendidikan berupa evaluasi proses pembelajaran dan kontribusi pendidikan tinggi terhadap pemerolehan kompetensi serta input pendidikan berupa penggalian lebih lanjut terhadap informasi sosiobiografis lulusan (Kemenristekdikti, 2016: 4). Relevansi Kurikulum adalah perkembangan ilmu pengetahuan dan teknologi dengan kebutuhan kerja diketahui dari beberapa hal diantaranya perkuliahan teori, praktik, materi, pengalaman PKL, kurikulum, dosen, iklim perkuliahan, dan kegiatan mahasiswa. Hasil Relevansi kurikulm dari 113 orang 3 orang memberikan nilai Cukup Baik $(41 \%-60 \%)$, 45 orang memberikan nilai Baik (61\%$80 \%), 65$ orang memberikan nilai Sangat Baik (81\%-100\%). Secara keseluruhan relevansi kurikulum dari 113 orang mendapatkan nilai 4370 poin dari 5085 poin maksimal, sehingga masuk dalam kategori sangat baik $(85,93 \%)$.

\section{SIMPULAN}

Berdasarkan dari hasil penelitian dapat ditarik kesimpulan bahwa mutu layanan prodi Ikor dalam pembiayaan sangat baik, diketahui bahwa pembiayan kuliahnya sebesar $26,55 \%$ dengan beasiswa dan sebesar 73,45 \% dengan biaya sendiri. Sedangkan mutu layanan pada kegiatan akademik hasilnya baik yaitu sebesar 79,27 \%. Lulusan Prodi Ikor dalam memperoleh pekerjaan sebesar 65,49\% sesudah lulus dengan rata-rata sebesar 3,47 bulan dan sebelum lulus sebesar 34,51\% dengan rata-rata sebesar 5,23 bulan. Kompetensi lulusan secara keseluruhan sangat baik yaitu $85,3 \%$ yang paling menonjol kompetensi dalam bekerjasama dengan tim atau dengan orang lain yaitu sebesar $88,5 \%$. Sedangkan untuk relevansi kurikulum diperoleh hasil sangat baik yaitu sebesar 85,93 \%, dalam relevansi kurikulum dari penilaian alumni persenstase yang paling tinggi yaitu sebesar $90,97 \%$ terdapat pada matakuliah praktik yang disampaikan saat kuliah sangat sesuai dengan kebutuhan kerja. Sehingga secara keseluruhan dapat disimpulkan bahwa penilaian alumni dalam penyelenggaraan mutu layanan dan relevansi kurikulum sebagian besar menyatakan sangat baik.

\section{DAFTAR PUSTAKA}

Arikunto. S. (2013). Prosedur penelitian; suatu pendekatan praktik. Jakarta: Rineka Cipta

Bustami. (2011). Penjaminan Mutu Pelayanan Kesehatan \& Akseptabilitasnya. Jakarta: Erlangga. 
Fajaryati, N., Priyanto, Sukardiyono, T., , Utami, A.D.W., Pambudi, S., \& Destian, B. (2015). Studi Penelusuran (Tracer Study) terhadap Alumni Program Studi Pendidikan Teknik Informatika Jurusan Pendidikan Teknik Elektronika Fakultas Teknik Universitas Negeri Yogyakarta. Jurnal Electronics, Informatics, and Vocational Education (ELINVO), Volume 1, Nomor 1, November 2015.

Fitzsimmons, James A and Mona J. Fitzsimmons. (2011). Service Management: Operations, Strategy, Information Technology 7th edition. The McGraw-Hill Internation Edition.

Kemendikbud. (2020). Peraturan Menteri Pendidikan dan Kebudayaan RI Nomor 5 Tahun 2020 tentang Akreditasi Program Studi dan Perguruan Tinggi . Jakarta, Kemendikbud

Kemendikbud. (2020). Peraturan Menteri Pendidikan dan Kebudayaan RI Nomor 7 Tahun 2020 tentang Pendirian, Perubahan, Pembubaran Perguruan Tinggi Negeri dan Pendirian, Perubahan, Pencabutan Izin Perguruan Tinggi Swasta . Jakarta, Kemendikbud

Kemenristekdikti. (2016). Panduan Hibah Tracer Studi Kemenristek dikti 2016. Direktorat Jenderal Pembelajaran dan Kemahasiswaan Kementerian Riset, Teknologi dan Pendidikan Tinggi

Kemenristekdikti. (2017). Pelaksanaan Tracer Study Tingkat Nasional. Surat Edaran No 2546/B3.4/KM/2017. Direktorat Jenderal Pembelajaran dan Kemahasiswaan Kementerian Riset, Teknologi dan Pendidikan Tinggi

Kemenristekdikti. (2017). Tentang Pelaksanaan Tracer Study di Perguruan Tinggi. Surat Edaran No. 471/B/SE/VII/2017. Direktorat Jenderal Pembelajaran dan Kemahasiswaan Kementerian Riset, Teknologi dan Pendidikan Tinggi.

Mas'ud, A. (2009). Analisis Tingkat Kepuasan Pelanggan terhadap Pelayanan Apotek Kimia Farma Jakarta Menggunakan Metode ServQual (Studi Kasus pada Tiga Apotek). Jurnal Kesehatan Masyarakat 4 (2):56-74.

Mubarak, W.I dan Chayatin, N. (2009). Ilmu Kesehatan MasyarakatTeori dan Aplikasi. Salemba Medika, Jakarta.

Mukti, A.G. (2007). Strategi Terkini Peningkatan Mutu Pelayanan Kesehatan : Konsep Implementasi.Yogyakarta. PT. Karya Husada Mukti. 326 hal

Muninjaya, Gde AA. (2011). Manajemen Mutu Pelayanan Kesehatan, Jakarta, EGC

Republik Indonesia .(2003). Undang-Undang RI Nomor 20, Tahun 2003, Tentang Sistem Pendidikan Nasional.

Republik Indonesia. (2012). Undang-Undang RI Nomor 12, Tahun 2012, Tentang Pendidikan Tinggi.

Republik Indonesia. (1945). Pembukaan Undang-Undang Dasar 1945.

Sugiyono. (2012) Metode penelitian pendidikan pendekatan kuantitatif, kualitatif, dan R \& D. Bandung: Alfabeta.

Suryatama, E. (2014). Aplikasi ISO Sebagai Standar Mutu. Jakarta : Kata Pena 